\title{
Correction to: A computational fluid dynamics approach to determine white matter permeability
}

\author{
Published online: 9 August 2019 \\ (C) The Author(s) 2019
}

Marco Vidotto $^{1,2}\left(\right.$ Daniela Botnariuc $^{3} \cdot$ Elena De Momi $^{1} \cdot$ Daniele Dini $^{2}$ as you give appropriate credit to the original author(s) and the source, provide a link to the Creative Commons license and indicate if changes were made.

The original article has been corrected.

The article "A computational fluid dynamics approach to determine white matter permeability" written by Marco Vidotto, Daniela Botnariuc, Elena De Momi and Daniele Dini was originally published electronically on the publisher's Internet portal (currently SpringerLink) on 20 February 2019 without open access.

With the author(s)' decision to opt for Open Choice, the copyright of the article changed on 8 August 2019 to (C) The Author(s) 2019 and the article is forthwith distributed under the terms of the Creative Commons Attribution 4.0 International License (http://creativecommons.org/licenses/ by/4.0/), which permits use, duplication, adaptation, distribution and reproduction in any medium or format, as long
Open Access This article is distributed under the terms of the Creative Commons Attribution 4.0 International License (http://creativeco mmons.org/licenses/by/4.0/), which permits use, duplication, adaptation, distribution and reproduction in any medium or format, as long as you give appropriate credit to the original author(s) and the source, provide a link to the Creative Commons license and indicate if changes were made.

Publisher's Note Springer Nature remains neutral with regard to jurisdictional claims in published maps and institutional affiliations.

The original article can be found online at https://doi.org/10.1007/ s10237-019-01131-7.

Marco Vidotto

marco.vidotto@polimi.it

1 Department of Electronics, Information and Bioengineering, Politecnico di Milano, 20133 Milan, Italy

2 Department of Mechanical Engineering, Imperial College London, London SW7 2AZ, UK

3 Faculty of Science, University of Lisbon, Campo Grande, 1149-016 Lisbon, Portugal 